\title{
Sequential, multi-taxon encrustation of an orthoceratid cephalopod by stalked blastozoan echinoderms in the middle Silurian (Wenlock Series) of southeastern Indiana, USA
}

\author{
James R. Thomka \& Thomas E. Bantel
}

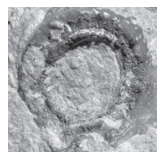

An orthoceratid cephalopod serving as a substratum for rare encrustation relationships is herein described from the middle Silurian (Wenlock Series, Sheinwoodian Stage) Massie Formation of southeastern Indiana, USA. The partial orthoconic cephalopod phragmocone is preserved as a flattened internal mold with some remnant shell material. The more damaged (presumably upward-facing) side is encrusted by the thecal attachment structure of a trematocystinid holocystitid diploporitan (probably Paulicystis), which is, in turn, encrusted by a dendritic attachment structure attributable to the hemicosmitid rhombiferan Caryocrinites. This represents an unusual form of multigenerational encrustation by blastozoan pelmatozoans; an encrustation that did not culminate in overgrowth of the cephalopod substratum. More importantly, this occurrence demonstrates preferential use of echinoderm remains as settling sites for later encrusting echinoderms, despite class-level taxonomic differences, and represents an additional example of utilization of a discrete macrofossil - and a rarely reported example of a coeval echinoderm attachment structure as a substratum for Caryocrinites attachment. Collectively, this material indicates that pelmatozoan encrustation of bioclasts in otherwise softground substrates is controlled by more complex factors than mere occurrence of available biomineralized material. $•$ Key words: Diploporita, Rhombifera, Massie Formation, Sheinwoodian, biotic interactions, attachment structures.

Thomka, J.R. \& Bantel, T.E. 2021. Sequential, multi-taxon encrustation of an orthoceratid cephalopod by stalked blastozoan echinoderms in the middle Silurian (Wenlock Series) of southeastern Indiana, USA. Bulletin of Geosciences 96(1), 53-59 (3 figures). Czech Geological Survey, Prague. ISSN 1214-1119. Manuscript received August 18, 2020; accepted in revised form November 6, 2020; published online November 27, 2020; issued January 10, 2021.

James R. Thomka, Center for Earth and Environmental Science, State University of New York at Plattsburgh, 132 Hudson Hall, Plattsburgh, New York 12901, USA; jthom059@plattsburgh.edu・Thomas E. Bantel, Dry Dredgers, P. O. Box 210-013, Cincinnati, Ohio 45221, USA

Encrustation of bioclasts by stalked echinoderms (pelmatozoans) in soft-substrate paleoenvironments is a wellknown and frequently documented phenomenon in Silurian marine strata (e.g., Brett 1984, 1991). Cephalopods are occasionally utilized as substrata by both crinoids and blastozoan taxa, in many cases representing the largest available hard substrate and therefore affecting the morphology of associated encrusting echinoderm attachment structures. In addition, aragonitic cephalopod shells that would otherwise have been completely destroyed by dissolution can be preserved via bioimmuration (sensu Taylor 1990) beneath overgrowing calcitic echinoderm skeletal structures. Hence, pelmatozoan encrustation of cephalopod shells has the potential to provide information on both echinoderm paleoautecology and cephalopod occurrence and preservation, making it worthwhile to document and carefully describe apparently noteworthy examples of this fossil association.
A collection of more than 100 nautiloid and orthoceratid cephalopods was recovered from the middle Silurian Massie Formation from southeastern Indiana, USA. This fauna contains several examples of cephalopod shells that were encrusted post mortem by various forms of stalked echinoderm. A full description of the entire collection is in progress; however, the present report focuses on a remarkable specimen that displays a rarely observed biotic association. Specifically, an orthoceratid shell is encrusted on one side by a pair of blastozoan echinoderm attachment structures belonging to two different classes of "cystoid" (Diploporita and Rhombifera). Not only is this an uncommon occurrence, but, more importantly, one attachment structure is directly encrusting the other rather than occupying a separate space on the surface of the cephalopod shell. This relationship has significance for the paleoautecology, paleosynecology and taphonomy of stalked echinoderm taxa in both soft- and hard-substrate environments. 


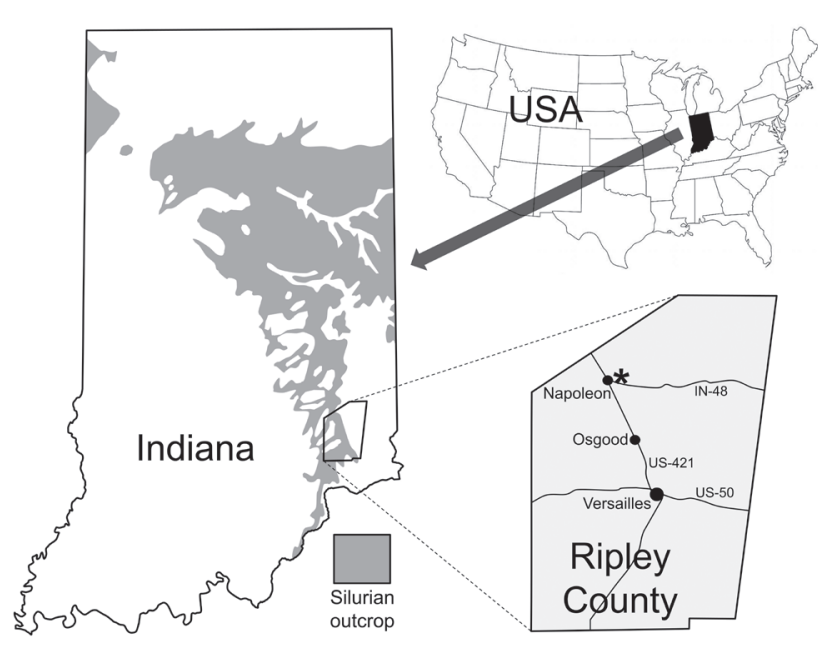

Figure 1. Location of specimen collection site, the New Point Stone quarry near Napoleon, northern Ripley County, southeastern Indiana, USA (marked by asterisk). The specimen was recovered from the lower portion of the mudstone lithofacies of the Massie Formation at this locality. Modified from Thomka \& Brett (2014b).

\section{Geographical, Stratigraphical and Sedimentological Context}

Studied material was collected from the active New Point Stone quarry located just outside of the town of Napoleon, northern Ripley County, southeastern Indiana, USA $\left(39^{\circ} 12^{\prime} 31.39^{\prime \prime} \mathrm{N}, 85^{\circ} 18^{\prime} 53.74^{\prime \prime} \mathrm{W}\right.$; Fig. 1). This locality is famous for its rich echinoderm fauna (Frest et al. 1999), particularly representatives of the middle Silurian Holocystites Fauna of diploporitan blastozoans, which are remarkably diverse and well-preserved in some stratigraphic intervals (Frest et al. 2011, Thomka et al. 2016). The uniqueness of the Napoleon quarry echinoderm fauna is further highlighted by the relatively pristine preservation of the sedimentary rocks within this extremely localized area, which is surrounded by Silurian exposures lacking fossils as a result of widespread late-diagenetic dolomitization (Thomka \& Brett 2015b).

The encrusted cephalopod was recovered from the mudstone lithofacies of the middle Silurian (Wenlock Series, Sheinwoodian Stage) Massie Formation, the lower decimeter of which is recognized as a Konservat Lagerstätte (Thomka et al. 2016). This unit consists of grey siliciclastic mudstone interbedded with thin fossiliferous packstones and represents the latest transgressive and highstand intervals of a third-order stratigraphic sequence (Brett et al. 2012, Thomka \& Brett 2015a). Evidence for episodic deposition by storm events is present throughout the Massie Formation, most notably in the form of articulated multielement echinoderm and trilobite skeletons (Frest et al. 1999, Thomka \& Brett 2015b, Thomka et al. 2016).
This interval, known as the 'upper Osgood shale' of Foerste (1897) prior to the lithostratigraphic revisions of Brett et al. (2012), contains the greatest abundance and diversity of stalked echinoderms (e.g., Frest et al. 1999, 2011; Thomka et al. 2016). It also contains a modest number of cephalopods, mostly belonging to the genera Dawsonoceras and Michelinoceras, as well as indeterminate orthoceratids. Cephalopods are most commonly preserved as internal molds with varying amounts of aragonitic shell material surrounding the infilling sedimentary rock. Cephalopod specimens typically display differential preservation on opposing sides of the phragmocone, with a more intact and pristine surface opposite a damaged and/or missing surface. This state of preservation closely matches that of most holocystitid diploporitans (Thomka et al. 2016), the most abundant echinoderm in the mudstone lithofacies of the Massie Formation.

\section{Description of Material}

Studied material is reposited in the Cincinnati Museum Center invertebrate paleontology collection (Cincinnati, Ohio, USA) under specimen number CMC IP 87723. The specimen consists of a partial orthoconic cephalopod of indeterminate generic identity. It resembles co-occurring specimens of Michelinoceras to some extent, but is best treated as Orthoceratida indet. It is $123 \mathrm{~mm}$ in length, $55 \mathrm{~mm}$ in width and $22 \mathrm{~mm}$ in maximum thickness (Fig. 2). A partial phragmocone, seemingly representing the middle to distal portion of the shell (based on degree of tapering) is present, preserved as an internal mold incompletely surrounded by original shell material. The specimen is strongly compressed, being nearly flattened perpendicular to its long axis, resulting in fracturing on both sides and buckling along the edges. This pushed one side, interpreted as the side that faced upward for most of the specimen's taphonomic history, down into the interior of the chambers (Fig. 2A). The opposite side, presumably the side that primarily faced downward (Fig. 2B), is more incomplete but is not compressed into the interior of the shell; it also displays a lighter color, has more shell material and contains less mud than the opposite side. There is no evidence that contradicts an interpretation of post-burial compression by sediment loading.

Both sides contain a small number of encrusting organisms, including bryozoans of several types and microconchids (see below), but these are minute. The largest and most prominent encrusting macrofossils are the focus of this study: these are found at the tip of the broader (i.e., adoral) end of the cephalopod shell, on what is interpreted as the upward-facing side (Figs 2A, 3).

Two pelmatozoan attachment structures, both attributable to blastozoan "cystoid" echinoderms, can be 


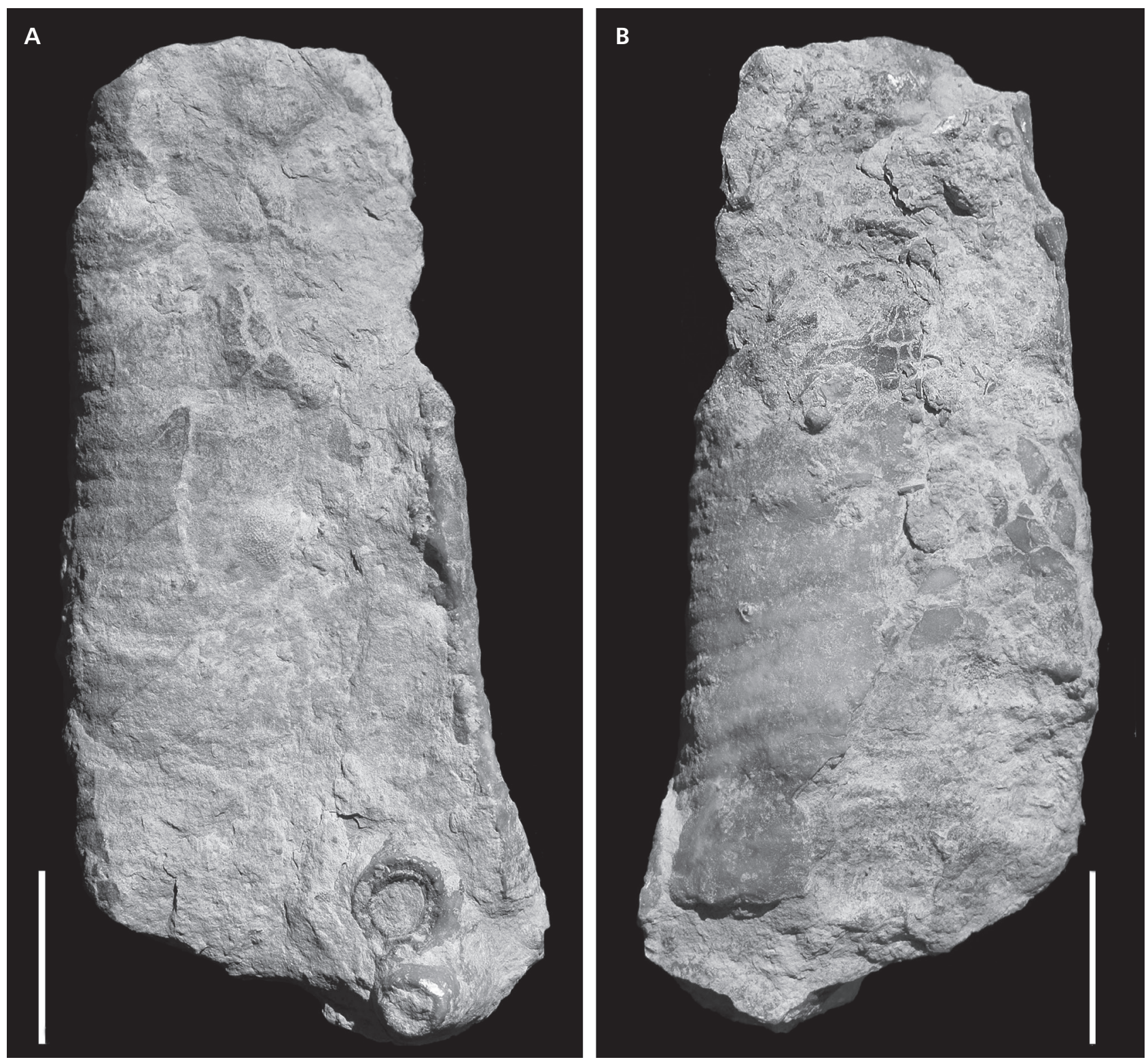

Figure 2. Orthoconic cephalopod (Orthoceratida indet.) encrusted by two blastozoan echinoderm attachment structures (CMC IP 87723). A - view of presumed upward-facing surface, with the echinoderm attachment structures visible on the lower portion of the image. This surface is also encrusted by small domal bryozoans. B - view of the opposite side of the specimen from that shown in Figure 2A, presumably representing the downward-facing side. This surface is encrusted by small domal and laminar bryozoans, microconchid tentaculitid molluscs and a portion of a crinoid column that may represent a dististelar attachment structure. All scale bars $=20 \mathrm{~mm}$.

identified as part of the encrusting fauna on the orthoceratid cephalopod shell (Fig. 3). Both are roughly discoidal, but it is clear that they belong to different taxa (notably, a diploporitan and a rhombiferan) and that one attachment structure encrusted and partially overgrew the other.

The encrusted diploporitan attachment structure is slightly ovoid in articular view, measuring $13 \mathrm{~mm}$ along the longest axis, which is oriented slightly oblique to the long axis of the cephalopod (Fig. 2A) by $9 \mathrm{~mm}$ along the shortest axis (Fig. 3A). It is medium brown in color and consists of a central, parabolic depressed area surrounded by a multi-plated ring. Component ossicles of the marginal ring structure contain pores that are faintly visible on the exterior of the specimen, and the sutures between adjacent ossicles are indistinct. The marginal ring structure contains an inner concentric structure that is highlighted by pyritization (Fig. 3A). The internal cavity is filled with sediment. The margins of the structure are also not clearly visible, being concealed by sediment on the upper surface of the cephalopod; however, the outermost edges of the attachment structure appear to be regular, with no lobate outgrowths (Fig. 3). 
This specimen is smaller than, but otherwise identical to, thecal attachment structures of holocystitid diploporitans described from a laterally extensive hardground surface capping the underlying basal carbonate lithofacies of the Massie Formation (Thomka \& Brett 2014a, b, 2015a). All visible morphological features ally this structure with the "type 1 holdfasts" of Thomka \& Brett (2014b) and the Paulicystis sp. attachment structures of Thomka \& Brett (2014a; see below).

The other echinoderm attachment structure, belonging to a rhombiferan, is found immediately adjacent to the one described above (Fig. 3), measuring $19 \mathrm{~mm}$ in maximum width and $13 \mathrm{~mm}$ in minimum width. The rhombiferan specimen is much more conical, measuring up to $12 \mathrm{~mm}$ in height and displaying pronounced outward flaring toward the substrate (Fig. 3B). The specimen is lighter in color than the associated diploporitan attachment, being light pinkish. The uppermost surface consists of an articulum, the details of which are covered by sediment (Fig. 3A); however, the narrow diameter suggests that a vertically oriented column was previously articulated. The portion of the basal attachment that is in contact with the diploporitan structure is modified into an outgrowth that partially surrounds the other specimen laterally (Fig. 3B). This surrounding outgrowth extends to roughly half of the width of the diploporitan attachment on the side closest to the lateral edge of the cephalopod shell (i.e., to the right of Figs 2A and 3A); the opposite sides of the specimens are covered by sedimentary matrix. Although there is no observable pathological swelling of the encrusted diploportan attachment in the area of contact - which would suggest a post mortem interaction - the secondarily encrusting echinoderm structure did not overgrow the depressed central cavity of the initial echinoderm settler. In fact, only a small portion of the marginal ring, closest to the center of the other attachment structure, is overgrown (Fig. 3).

This second echinoderm attachment structure can be reliably attributed to the hemicosmitid rhombiferan Caryocrinites, a taxon that is known from the mudstone lithofacies of the Massie Formation at the Napoleon quarry (Frest et al. 1999, 2011) as well as the underlying basal carbonate lithofacies (Thomka \& Brett 2015a). Despite the diagnostic trilobate columnal lumen (Brett 1978, 1981) being concealed by sedimentary infill, identifiable traits include radicles (in this specimen, represented by the short outgrowths surrounding the diploporitan attachment) that are composed of solid calcite (Brett 1978) and the light pinkish colour, which is typical for Caryocrinites attachment structures at this locality (Thomka \& Brett 2014b). Most convincingly, nearly identical structures, including those partially encrusting similar diploporitan thecal attachments (Thomka \& Brett 2014b, fig. 8c, d), have been described from an immediately underlying hardground surface (Thomka \& Brett 2015a, fig. 5e).
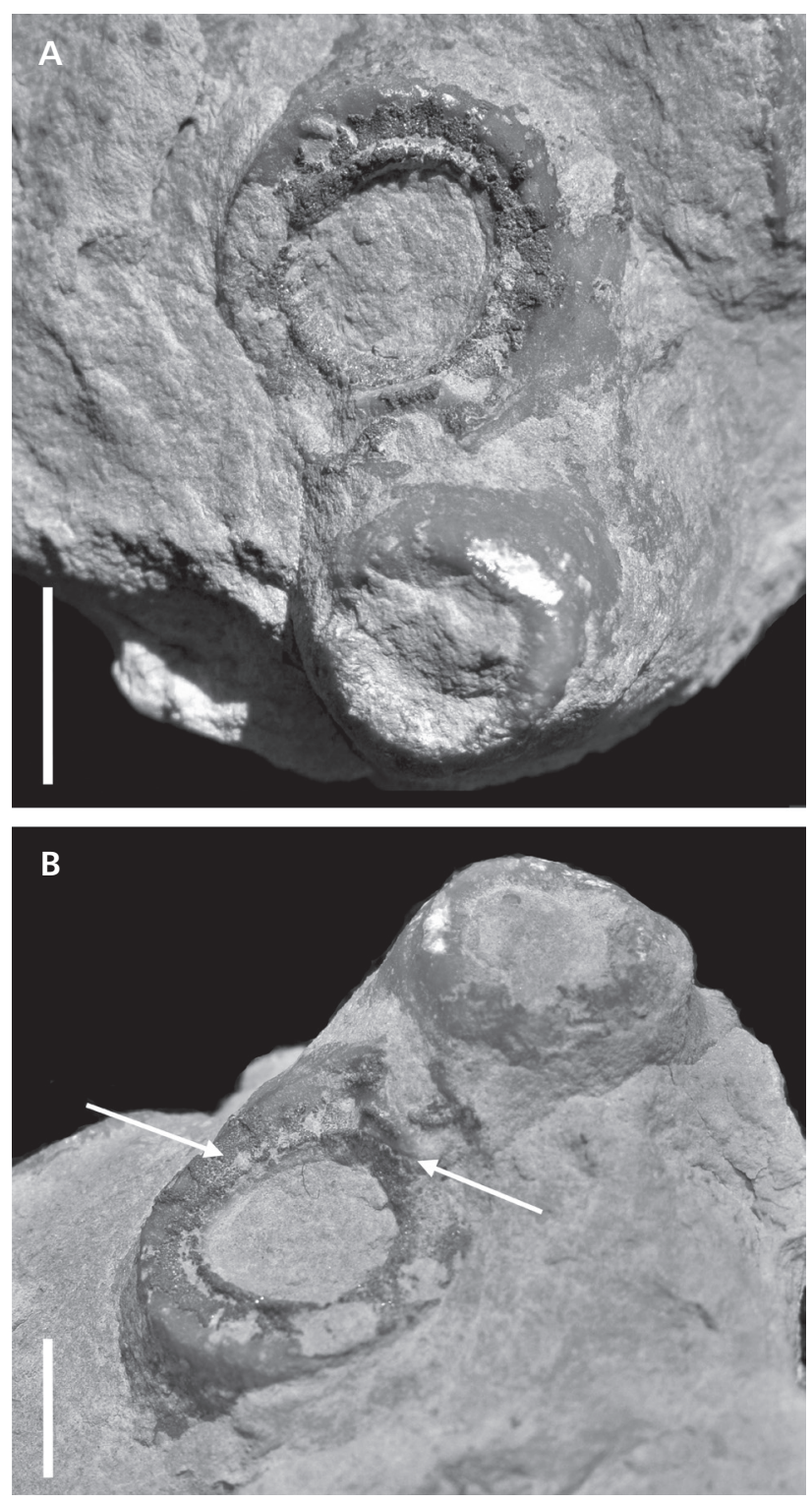

Figure 3. Close-up views of the encrusting echinoderm attachment structures on an orthoceratid cephalopod (CMC IP 87723). A - articular view of both attachment structures. The upper, darker specimen represents the thecal attachment of a trematocystinid holocystitid diploporitan, probably Paulicystis sp. The lower, lighter specimen represents the terminal radicular attachment structure of the hemicosmitid rhombiferan Caryocrinites sp., which is modified from its typical dendritic morphology. B - oblique view of echinoderm attachment structures, showing the overgrowth of the diploporitan attachment by an outgrowth (modified radicle) of the rhombiferan attachment. The contact between the attachment structures is highlighted by the arrows. All scale bars $=10 \mathrm{~mm}$.

\section{Discussion}

\section{Implications for Blastozoan Paleoecology}

Blastozoan echinoderms utilize a variety of hard substrata for encrustation, at least during certain phases of ontogeny 
(e.g., Brett 1981, Gil Cid \& Domínguez-Alonso 2000, Frest et al. 2011). In softground settings, the primary mode of attachment is cementation to isolated lithoclasts and bioclasts; within the mudstone lithofacies of the Massie Formation, initial settlement by holocystitid diploporitan larvae typically occurred on small shell fragments, which were then overgrown as the aboral region increased in diameter or abandoned as the diploporitan transitioned to a recumbent position (Paul 1971, Frest et al. 2011). To our knowledge, the specimen described in this study is the first published example of diploporitan utilization of a large, relatively intact cephalopod - that was not overgrown and incorporated into the aboral region - as a substrate. Further, the development of a diploporitan aboral thecal attachment structure that is adapted to permanently occupy part of a larger, hard substrate rather than a minute bioclast that could be overgrown throughout ontogeny stands in stark contrast to the attachment strategy generally adopted in fine-grained softgrounds (Gil Cid \& Domínguez-Alonso 2000), including the mudstone lithofacies of the Massie Formation (Paul 1971, Frest et al. 2011). That is, this style of substrate affixation is identical to that employed by holocystitid diploporitans that encrusted a laterally continuous hardground surface (Thomka \& Brett 2014a, b). Thus, holocystitid diploporitans possessed sufficient morphological plasticity in their aboral regions to adopt a "hardground-style" encrustation strategy when exposed to a relatively large bioclast (i.e., a fairly intact cephalopod shell) even in an environment otherwise characterized by fine grain size and a softground substrate consistency.

The preferential encrustation of a diploporitan attachment structure by the distal radicular structure of $\mathrm{Ca}$ ryocrinites is particularly noteworthy. Despite the occurrence of Caryocrinites dendritic attachment structures in a diversity of substrate types - including mud-dominated softgrounds, coarse rubble-dominated softgrounds and hardgrounds - detailed studies in each environment demonstrated that individuals initially settled upon isolated bioclasts, almost universally ramose bryozoans, before overgrowing them and extending radicles into surrounding material (Brett 1978, 1984, 1991). Preferential settlement on, and overgrowth of, a diploporitan attachment structure shows that Caryocrinites sought out discrete bioclasts even in settings where space on a bare hard surface was readily available as a potential encrustation site. In addition, this specimen demonstrates that Caryocrinites did not strictly require ramose bryozoans as initial settlement sites, and would (?opportunistically) encrust other macrofossils, perhaps preferring the largest material.

The association between these two echinoderm attachment structures does not reflect simple co-occurrence on a portion of the cephalopod shell that was exposed while the rest was buried by sediment. The primary reason for this is the presence of other encrusting organisms, including small bryozoan zoaria on the same side of the specimen as the echinoderms; and similar bryozoans, minute tubes most likely representing microconchid tentaculitoids (see Zatoń \& Vinn 2011) and a small, thin segment of crinoid column that may represent part of a recumbent dististelar attachment structure (see Brett 1981) on the opposite side of the specimen (Fig. 2). Hence, substantial portions, if not the entirety, of both sides of the cephalopod shell must have been exposed for long enough to become encrusted; this was clearly not a shell that was partially buried with only the small portion occupied by the echinoderms left emergent. Additional evidence suggesting a preference for Caryocrinites settlement on diploporitan attachments comes from the undulating hardground underneath the mudstone lithofacies of the Massie Formation: here, weathered diploporitan attachment structures were consistently overgrown by Caryocrinites structures on laterally extensive, stable, hard areas with an abundance of available bare surface (Thomka \& Brett 2014b, 2015a).

In a larger sense, rhombiferan encrustation of a diploporitan attachment structure represents a relatively rare occurrence of a blastozoan echinoderm utilizing another blastozoan as a substrate. Previously described examples consist nearly entirely of adult specimens encrusted by small, temporary holdfasts belonging to juveniles in monospecific echinoderm assemblages, most notably the Middle Ordovician "cystoid limestones" of Scandinavia (e.g., Paul \& Bockelie 1983, Bockelie 1984, Frest et al. 2011). Examples of two different echinoderm classes involved in an encruster-substrate or epibiont-host relationship are not unknown (e.g., Sumrall 2000; Thomka et al. 2016, fig. 6d), but there are few published reports of two different blastozoan classes engaged in such interactions (see Sprinkle 1973). The occurrence described here contributes to the sparse literature on representatives of one blastozoan class encrusting the skeletal remains of a representative of a different blastozoan class.

\section{Identity of Encrusting Diploporitan}

Holocystitid diploporitan encrustation of nautiloid and orthoceratid cephalopods in the Massie Formation has previously been documented, specifically by the genera Paulicystis and Pentacystis (Paul 1971; Frest et al. 2011, tab. 5); however, all of the figured specimens in these monographic treatments that utilized cephalopods as substrata had evidently encrusted relatively small fragments, which were completely overgrown by the aboral region of the diploporitans (e.g., Frest et al. 2011, pl. 10, fig. 5; pl. 11, fig. 6). Among these taxa, Paulicystis was reported to be encrusted only by bryozoans, and Pentacystis by bryozoans, "worm tubes" and the tabulate 
coral Favosites (Frest et al. 2011, tab. 8) - neither genus was reported as having been encrusted by pelmatozoan attachment structures. Instead, diploporitan taxa reported as serving as substrata for other pelmatozoans in the mudstone lithofacies of the Massie Formation are Triamara (rarely), Holocystites and Osgoodicystis (uncommonly), with Trematocystis being most frequently encrusted by other echinoderms (Frest et al. 2011, tab. 8).

Thus, based on documented encruster-host relationships alone, it seems that the diploporitan thecal attachment structure that first encrusted the orthoceratid was almost certainly a trematocystinid holocystitid: Paulicystis shows a preference for encrusting cephalopods and Trematocystis shows a preference for being encrusted by other stalked echinoderms. These are closely related genera (Frest et al. 2011 ) and both are characterized by broad aboral regions capable of producing similar-looking structures found on an immediately underlying hardground surface at the Napoleon quarry (Thomka \& Brett 2014a). Morphological differences between the aboral regions of Paulicystis and Trematocystis are insufficient to convincingly distinguish one genus from the other based on isolated attachment structures alone, but we are inclined to view Paulicystis as the more likely producer based on the very close similarity to structures ascribed to this genus by Thomka \& Brett (2014a). Regardless, either of these trematocystinids could have utilized the orthoceratid shell as a hard substrate.

\section{Broader Significance and Conclusions}

The occurrence of an orthoceratid cephalopod that was encrusted by a trematocystinid holocystitid diploporitan (probably Paulicystis) which was, itself, encrusted by a hemicosmitid rhombiferan (Caryocrinites) is significant for several reasons. First, this specimen represents the first detailed description of a relatively large, fairly intact cephalopod shell that was encrusted, but not overgrown, by a diploporitan echinoderm. Second, this specimen demonstrates that holocystitid diploporitans were capable of modifying their aboral regions to adopt a "hardgroundstyle" encrustation strategy - otherwise known from laterally continuous lithified surfaces - in a muddy softground environment if sufficiently large bioclasts are available. Third, this specimen preserves an example of one blastozoan class encrusting another blastozoan class, a taphonomic and paleoecological phenomenon that is rarely recorded. Fourth, the preferential encrustation of diploporitan skeletal material by the modified dendritic radicular attachment structure of Caryocrinites strongly supports the interpretation that this common and widespread taxon generally required a discrete macrofossil for initial settlement, even in settings where a hard surface was readily available for occupation.
Beyond the aspects listed above, the broader significance of this study stems from the fact that pelmatozoan echinoderms and orthoceratid cephalopods are both common in middle Silurian (and, indeed, middle Paleozoic) marine environments, but significant and/or rare specimens recording interactions between them - albeit after the death of the cephalopod in this case - continue to be discovered. Likewise, the blastozoan echinoderm fauna of the Napoleon quarry has been extensively studied, yet continues to produce noteworthy material. It is hoped that ongoing collecting, documentation and reinvestigation steadily yields even more interesting finds from a site that has not yet run dry.

\section{Acknowledgments}

The Wanstrath family of Napoleon, Indiana, USA, graciously allowed access to the collection site. Research into the stratigraphy and paleontology of the Napoleon quarry locality has been significantly enhanced through discussions with Carlton E. Brett (University of Cincinnati) and Donald L. Bissett (Dry Dredgers). Brenda R. Hunda and Cameron E. Schwalbach (Cincinnati Museum Center) facilitated reposition of the specimen. Previous versions of this paper were improved by the constructive reviews provided by David Evans (Natural England) and Martina Aubrechtová (Charles University).

\section{References}

Bockelie, J.F. 1984. The Diploporita of the Oslo region, Norway. Palaeontology 27, 1-27.

Brett, C.E. 1978. Attachment structures in the rhombiferan Caryocrinites and their paleobiological implications. Journal of Paleontology 52, 717-726.

BRETT, C.E. 1981. Terminology and functional morphology of attachment structures in pelmatozoan echinoderms. Lethaia 14, 343-370. DOI 10.1111/j.1502-3931.1981.tb01110.x

Brett, C.E. 1984. Autecology of Silurian pelmatozoan echinoderms, 87-120. In Bassett, M.G. \& Lawson, J.D. (eds) Autecology of Silurian organisms, Special Papers in Palaeontology 32.

Brett, C.E. 1991. Organism-sediment relationships in Silurian marine environments, 301-344. In Bassett, M.G., LANE, E.D. \& EDWARDS, D. (eds) The Murchison symposium: proceedings of an international symposium on the Silurian System, Special Papers in Palaeontology 44.

Brett, C.E., Cramer, B.D., McLaughlin, P.I., Kleffner, M.A., Showers, W.J. \& ThomkA, J.R. 2012. Revised TelychianSheinwoodian (Silurian) stratigraphy of the Laurentian midcontinent: Building uniform nomenclature along the Cincinnati Arch. Bulletin of Geosciences 87, 733-753.

DOI 10.3140/bull.geosci.1310

Foerste, A.F. 1897. A report on the Middle and Upper Silurian rocks of Clark, Jefferson, Ripley, Jennings, and southern 
Decatur Counties, Indiana. Indiana Department of Geology and Natural Resources Annual Report 21, 213-288.

Frest, T.J., Brett, C.E. \& Witzke, B.J. 1999. Caradocian to Gedinnian echinoderm associations of central and eastern North America, 638-783. In Boucot, A.J. \& Lawson, J.D. (eds) Paleocommunities: a case study from the Silurian and Lower Devonian. Cambridge University Press, Cambridge.

Frest, T.J., Strimple, H.L. \& Paul, C.R.C. 2011. The North American Holocystites fauna (Echinodermata, Blastozoa: Diploporita): Paleobiology and systematics. Bulletins of American Paleontology 380, 1-141.

Gil Cid, M.D. \& Domínguez-Alonso, P. 2000. Attachment strategies in Diploporita inhabiting soft-substratum communities, 83-86. In BARKER, M. (ed.) Echinoderms 2000. Swets and Zeitlinger, Lisse.

Paul, C.R.C. 1971. Revision of the Holocystites fauna (Diploporita) of North America. Fieldiana: Geology 24, 1-166. DOI 10.5962/bhl.title.3412

Paul, C.R.C. \& Bockelie, J.F. 1983. Evolution and functional morphology of the cystoid Sphaeronites in Britain and Scandinavia. Palaeontology 26, 687-734.

Sprinkle, J. 1973. Morphology and evolution of blastozoan echinoderms. 283 pp. Harvard University Museum of Comparative Zoology Special Publication, Cambridge. DOI 10.5962/bhl.title.66379

Sumrall, C.D. 2000. The biological implications of an edrioasteroid attached to a pleurocystitid rhombiferan. Journal of Paleontology 74, 67-71.

DOI 10.1666/0022-3360(2000)074<0067:TBIOAE $>2.0$. CO;2

TAYLOR, P.D. 1990. Preservation of soft-bodied and other organisms by bioimmuration-A review. Palaeontology 33, 1-17.

Thomka, J.R. \& Brett, C.E. 2014a. Diploporite (Echinodermata, Blastozoa) thecal attachment structures from the Silurian of southeastern Indiana. Journal of Paleontology 88, 179-186. DOI 10.1666/12-142

Thomka, J.R. \& Brett, C.E. 2014b. Taphonomy of diploporite (Echinodermata) holdfasts from a Silurian hardground, southeastern Indiana, United States: Palaeoecologic and stratigraphic significance. Geological Magazine 151, 649-665. DOI 10.1017/S001675681300068X

Thomka, J.R. \& Brett, C.E. 2015a. Paleoecology of pelmatozoan attachment structures from a hardground surface in the middle Silurian Massie Formation, southeastern Indiana. Palaeogeography, Palaeoclimatology, Palaeoecology 420, 1-12. DOI 10.1016/j.palaeo.2014.12.001

Thomka, J.R. \& Brett, C.E. 2015b. Palaeontological and sedimentological effects of micro-bioherms in the Middle Silurian Massie Formation of southeastern Indiana, USA. Lethaia 48, 172-187. DOI 10.1111/let.12097

Thomka, J.R., Brett, C.E., Bantel, T.E., Young, A.L. \& Bissett, D.L. 2016. Taphonomy of 'cystoids' (Echinodermata: Diploporita) from the Napoleon quarry of southeastern Indiana, USA: The Lower Silurian Massie Formation as an atypical Lagerstätte. Palaeogeography, Palaeoclimatology, Palaeoecology 443, 263-277. DOI 10.1016/j.palaeo.2015.11.034

ZATOŃ, M. \& VinN, O. 2011. Microconchids and the rise of modern encrusting communities. Lethaia 44, 5-7. DOI $10.1111 / \mathrm{j} .1502-3931.2010 .00258 . x$ 